\title{
EVALUATION OF SOIL POLLUTION BY SOME HEAVY METALS VIA ATOMIC ABSORPTION SPECTROPHOTOMETER (AAS) TECHNIQUE IN ZAKHO DISTRICT, KURDISTAN REGION - IRAQ
}

Jindy M. Jindy a, * , Amin K. Qasim ${ }^{\text {a }}$, Sagvan A Mohamed ${ }^{\text {a }}$

${ }^{\text {a }}$ Dept. of Chemistry, Faculty of Science, University of Zakho, Kurdistan Region, Iraq - (jindy.murad@uoz.edu.krd)

Received: Oct., 2020 / Accepted: Nov., 2020 / Published: Dec.,2020

https://doi.org/10.25271/sjuoz.2020.8.4.765

\begin{abstract}
:
In this study, the atomic absorption spectrophotometer (AAS) technique has been used in analysing 26 soil samples for five heavy metals: $\mathrm{Pb} 2+, \mathrm{Cu} 2+, \mathrm{Zn} 2+, \mathrm{Cr} 3+$ and Ni2+ in Zakho district, Kurdistan region - Iraq. Heavy metals can be accrued to the soil during the releases of industrial waste, removal of extraordinary quality metal waste, petrochemical falls and etc. In all soil samples, heavy metals concentration was found in the range of $0.541-4.339 \mathrm{mg} / \mathrm{L}$ for $\mathrm{Pb}, 0.118-0.797 \mathrm{mg} / \mathrm{L}$ for Cu, $1.260-5.540 \mathrm{mg} / \mathrm{L}$ for $\mathrm{Zn}, 1.315-2.102 \mathrm{mg} / \mathrm{L}$ for $\mathrm{Cr}$ and $1.049-1.635 \mathrm{mg} / \mathrm{L}$ for Ni. As shown in the result, the heavy metals concentration contents increases with fossil fuel combustion, industrial releases, and agricultural activities. However, the results of the AAS technique was found that the high concentration element $\mathrm{Pb}$ and $\mathrm{Zn}$ were determined than the other elements like $\mathrm{Cu}, \mathrm{Cr}$ and $\mathrm{Ni}$ but less than acceptable limits in all cases. Regarding to achieve data in the recent research, soil of case study can be relatively considered unpolluted, healthy and it is suitable for growth plants and usable for other purposes.
\end{abstract}

KEYWORDS: Heavy metals, Soil, Atomic absorption spectrophotometer (AAS), Zakho district.

\section{INTRODUCTION}

The rapid increase of urbanization, industrialization, and mobile traffic in many areas around the world leads to environmental contamination and impacts directly on human health. Eventually, it may pose a serious risk to the urban residents and effect soil ecosystem services[1, 2]. Heavy metals may enter into human body via food and water which are contaminated by them or by inhaling polluted dust particles. When they enter the human body, they will transfer through the blood into various organs causing several health problems like carcinogen and lung cancer [3, 4]. Meanwhile, one of the most important indicators to determine anthropogenic contamination in our environment is urban soil[5]. Until now, large amounts of information are still missed in the rapidly developing countries and semiarid areas[2], including our study zone. Therefore, comprehensive investigations and researches are necessary in those areas to identify the reality of the case clearly [1]. Development in urban areas increases gaseous and particulate emissions from industrial, residential activities, traffic and waste management $[1,2,6]$. These emissions are the most leading sources of potential toxic elements (PTEs) and organic pollutants $[5,7]$. The most popular PTEs in urban soils come from anthropogenic activities are $\mathrm{Pb}, \mathrm{Cd}, \mathrm{Cu}, \mathrm{Zn}$, $\mathrm{Hg}, \mathrm{Cr}, \mathrm{Co}$ and $\mathrm{Ni}[4,5,7,8]$. The type and extent of soil contamination is linked to the intensity of anthropogenic impact and varies between recreational, residential, traffic and industrial areas[8]. The consequence is that determination and assessment of contamination of urban soils is actually necessary for the evaluation of environmental quality and protection $[1,2]$.

Therefore, the current study focuses on the concentration of several heavy metals, such as anthropogenic urban soil pollutants, in Zakho city. According to a profound research of whether or not such studies have been made in this particular location, our study is found the first in its type in that specific location. Therefore, the results of investigation are compared to the allowable levels worldwide as shown in the Tab 2. Hence, the first aim of the study is to identify and assess heavy metal contamination situation of urban soils in Zakho city. For this purpose, samples were collected to investigate each of $\mathrm{Cr}, \mathrm{Pb}, \mathrm{Zn}, \mathrm{Cu}$ and $\mathrm{Ni}$ as representative indicators of PTEs. Other objectives are as follow: to identify impacts of industrial activities and traffic on soil in the area, and to compare the concentration of heavy metals in urban soil with the concentration of heavy metals in urban road dusts of Zakho city.

\section{MATERIALS AND METHODS}

\subsection{Study area}

The experimental site covers different land use sites in Zakho city. Zakho district is one of the seven districts in Duhok governorate and the second largest city according to General Board of Tourism in Kurdistan Region- Iraq. It is located in the northern part of the country, $8 \mathrm{~km}$ west of Ibrahim Khalil crossing border point with Turkey[9]. The city is subjected to an extremely dry and hot weather in summer from May to August, mild and wet in winter from October to March. The current study focuses mainly on the main and commercial road between Ibrahim Khalil crossing border with Turkey and Zakho city including the down town of the city. In the study area, various land uses are to be seen like; agricultural area, river bank, industrial area, residential area (Fig. 1).

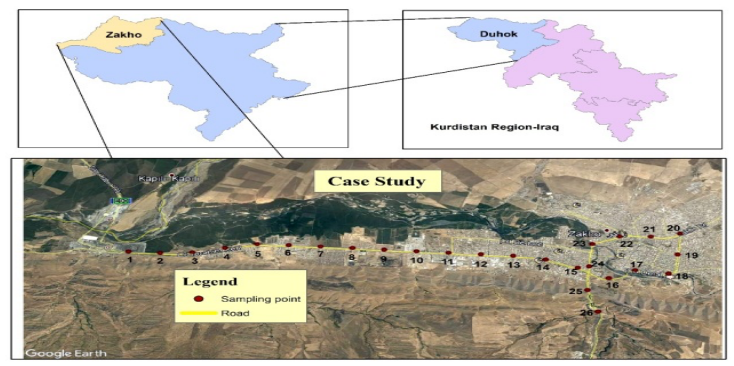

Figure 1. Location of Zakho city within Kurdistan Region - Iraq and soil sampling sites, satellite image from Google Earth 2018.

* Corresponding author

This is an open access under a CC BY-NC-SA 4.0 license (https://creativecommons.org/licenses/by-nc-sa/4.0/) 


\subsection{Sample Collection}

Samples were collected from 26 different locations, with distance $600 \mathrm{~m}$ between each of the locations using clean shovel. Samples were taken from surface soil at $5 \mathrm{~cm}$ depth around the sample area. About $1 \mathrm{~g}$ of soil samples, which are sufficient for getting the required amount for atomic absorption spectroscopy. However, the samples were mixed, gently homogenized and grind with a mortar and pestle through 200mm-mesh sieve. The samples were first air dried and then placed in an electric oven at a temperature of $105^{\circ} \mathrm{C}$ for $24 \mathrm{~h}$. Finally, the samples were stored in plastic vials with the code of the sample to the time of analysis.

\subsection{Digestion of soil samples}

The experimental technique for digestion of soil samples is the same as reported elsewhere $[10,11] .1 \mathrm{~g}$ of the oven dried sample was weighed using a top loading balance and placed in a $250 \mathrm{ml}$ Beakers separately, to which $15 \mathrm{ml}$ of a mixture of $\left(14 \% \mathrm{HCl}\right.$ and $70 \%$ high purity $\mathrm{HNO}_{3}$, in $3: 1$ ratio) was added. The mixture was then digested at $80^{\circ} \mathrm{C}$ till the solution became transparent. The resulting solution was filtered through Whatman filter paper no. 42, and into a $100 \mathrm{ml}$ dilute to $100 \mathrm{ml}$ volumetric flask and diluted to mark volume using deionised water. The sample solution was analysed for concentrations of $\mathrm{Cu}, \mathrm{Zn}, \mathrm{Pb}, \mathrm{Ni}$ and $\mathrm{Cr}$ using an atomic absorption spectrometer (Perkin-Elmer, PinAAcle 900 AAS Consumables and Supplies). Each sample, for each element, was automatically measured with three replicates by AAS instrument.

\subsection{Analysis of soil samples}

Heavy metals $(\mathrm{Cu}, \mathrm{Zn}, \mathrm{Pb}, \mathrm{Ni}$ and $\mathrm{Cr})$ in the previously digested soil samples were estimate using atomic absorption spectroscopy AAS (Perkin-Elmer, PinAAcle 900 AAS Consumables and Supplies). This enables elemental analysis at percentage to parts per million ( $\mathrm{ppm}$ ) levels for a wide range of metals. The analytical blank was prepared, and standard solutions used in calibration were prepared by diluting multi-elemental standard solutions of concentration of $100 \mathrm{mg} / \mathrm{l}$. The blank and standards were atomized in turn and their responses measured. A calibration graph was plotted for each of the solutions, after which the sample solutions were atomized and measured. The various metal concentrations from the sample solution were determined from the calibration, based on the absorbance obtained for the unknown sample.

\subsection{Statistical analysis}

Data were analysed using one-way ANOVA analysis for each of the metals which are studied separately. Significant differences between crop types were illustrated at the 0.05 probability level of significant using Turkey HDS test carried out using IBMSPSS version 2.3 software. Normality data were tested by using Kolmogorov-Smirnov and Shapiro test in IBM-SPSS software.

\section{RESULTS AND DISCUSSION}

Total contents of $\mathrm{Pb}, \mathrm{Cu}, \mathrm{Ni}, \mathrm{Cr}$ and $\mathrm{Zn}$ in the $0-5 \mathrm{~cm}$ surface layer of soils from the different sampling areas of the variation between different stations of the road (from Ibrahim Khalil to Zakho), urban area (Zakho city) and outlet road of Zakho to Duhok are shown in Table 1 and Figure 1 - 5.

The results of the study revealed that the concentration of the heavy metals were low in the first station and increased gradually, with some fluctuations, until the industrial area. That records the highest level of $\mathrm{Cu}, \mathrm{Cr}$ and $\mathrm{Cu}$ with high concentration of $\mathrm{Zn}$ and $\mathrm{Pb}$. The level of all measured heavy metals has been decreased in the final two stations, except $\mathrm{pb}$ because of the automobile traffic which are away from the urban area. The charts which have been obtained by using each of the heavy metal concentrations at the 26 points.

The order of the concentration of metals was in the following form $\mathrm{Pb}>\mathrm{Zn}>\mathrm{Cr}>\mathrm{Ni}>\mathrm{Cu}$. This refers mostly to the pollution coming from different sources, as well as from geological formation of the area (discussed in details in discussion.

Table 1. Mean concentration and standard deviation of $\mathrm{Cu}, \mathrm{Zn}, \mathrm{Pb}, \mathrm{Cr}$ and $\mathrm{Ni}$ in study area.

\begin{tabular}{|c|c|c|c|c|c|c|c|c|c|c|}
\hline \multirow{2}{*}{ Station } & \multicolumn{2}{|c|}{ Cu (mg/L) } & \multicolumn{2}{c|}{ Zn (mg/L) } & \multicolumn{2}{c|}{ Pb (mg/L) } & \multicolumn{2}{c|}{ Cr (mg/L) } & \multicolumn{2}{c|}{ Ni (mg/L) } \\
\cline { 2 - 11 } & Mean & St.Dev & Mean & St.Dev & Mean & St.Dev & Mean & St.Dev & Mean & St.Dev \\
\hline S1 & 0.279 & 0.015 & 1.76 & 0.237 & 0.541 & 0.129 & 1.612 & 0.023 & 1.049 & 0.335 \\
\hline S2 & 0.587 & 0.007 & 2.66 & 0.571 & 1.213 & 0.248 & 1.847 & 0.029 & 1.391 & 0.038 \\
\hline S3 & 0.589 & 0.034 & 2.66 & 0.425 & 1.027 & 0.074 & 1.495 & 0.033 & 1.025 & 0.028 \\
\hline S4 & 0.395 & 0.041 & 3.46 & 0.435 & 0.939 & 0.099 & 1.493 & 0.094 & 1.128 & 0.087 \\
\hline S5 & 0.327 & 0.052 & 5.54 & 0.445 & 1.006 & 0.142 & 1.467 & 0.292 & 1.097 & 0.223 \\
\hline S6 & 0.382 & 0.042 & 2.66 & 0.361 & 1.591 & 0.163 & 1.552 & 0.001 & 1.13 & 0.043 \\
\hline S7 & 0.348 & 0.061 & 1.9 & 0.316 & 1.203 & 0.043 & 1.591 & 0.116 & 1.197 & 0.108 \\
\hline S8 & 0.413 & 0.041 & 3.58 & 0.568 & 1.503 & 0.085 & 1.472 & 0.083 & 1.087 & 0.038 \\
\hline S9 & 0.524 & 0.11 & 2.54 & 0.036 & 1.84 & 0.222 & 1.643 & 0.084 & 1.181 & 0.045 \\
\hline S10 & 0.49 & 0.064 & 2.58 & 0.173 & 1.949 & 0.199 & 1.622 & 0.032 & 1.191 & 0.063 \\
\hline S11 & 0.385 & 0.021 & 2.44 & 0.308 & 1.826 & 0.252 & 1.668 & 0.024 & 1.183 & 0.104 \\
\hline S12 & 0.554 & 0.054 & 1.78 & 0.466 & 2.165 & 0.083 & 1.903 & 0.131 & 1.348 & 0.121 \\
\hline S13 & 0.773 & 0.178 & 2.38 & 0.635 & 2.486 & 0.039 & 1.834 & 0.105 & 1.229 & 0.089 \\
\hline S14 & 0.414 & 0.05 & 2.26 & 0.743 & 2.319 & 0.291 & 2.102 & 0.118 & 1.539 & 0.199 \\
\hline S15 & 0.385 & 0.001 & 1.26 & 0.245 & 2.29 & 0.12 & 1.823 & 0.077 & 1.274 & 0.044 \\
\hline S16 & 0.498 & 0.012 & 2.22 & 0.223 & 2.253 & 0.577 & 1.854 & 0.159 & 1.34 & 0.158 \\
\hline S17 & 0.479 & 0.015 & 1.74 & 0.39 & 2.13 & 0.093 & 1.928 & 0.024 & 1.447 & 0.053 \\
\hline S18 & 0.421 & 0.085 & 1.58 & 0.209 & 2.749 & 0.203 & 1.814 & 0.059 & 1.284 & 0.054 \\
\hline S19 & 0.705 & 0.002 & 2.28 & 0.355 & 4.339 & 0.123 & 1.945 & 0.052 & 1.353 & 0.013 \\
\hline S20 & 0.469 & 0.006 & 1.78 & 0.377 & 2.835 & 0.02 & 1.975 & 0.067 & 1.436 & 0.026 \\
\hline S21 & 0.622 & 0.027 & 3.04 & 0.509 & 3.185 & 0.138 & 1.934 & 0.047 & 1.323 & 0.012 \\
\hline S22 & 0.477 & 0.013 & 1.94 & 0.281 & 3.206 & 0.067 & 1.93 & 0.024 & 1.394 & 0.031 \\
\hline
\end{tabular}




\begin{tabular}{|c|c|c|c|c|c|c|c|c|c|c|} 
S23 & 0.797 & 0.138 & 1.86 & 0.219 & 3.481 & 0.048 & 2.09 & 0.226 & 1.565 & 0.241 \\
\hline S24 & 0.55 & 0.14 & 1.88 & 0.357 & 3.691 & 0.125 & 1.95 & 0.131 & 1.577 & 0.231 \\
\hline S25 & 0.369 & 0.097 & 1.66 & 0.411 & 3.018 & 0.243 & 1.943 & 0.264 & 1.635 & 0.073 \\
\hline S26 & 0.188 & 0.034 & 2.02 & 0.382 & 3.152 & 0.049 & 1.315 & 0.05 & 1.073 & 0.077 \\
\hline
\end{tabular}

\subsection{Lead $\left(\mathrm{Pb}^{2+}\right)$}

According to the AAS results, the concentrations of the lead $\left(\mathrm{pb}^{2+}\right)$ ion in the soil samples are less than the acceptable limit of lead in soil which is $(400-500 \mathrm{mg} / \mathrm{L})$ [12]. As the Table 1 shows, the $\mathrm{S} 19$ is $4.339 \mathrm{mg} / \mathrm{L}$ the highest concentration of the lead recorded by AAS technique and the sample was taken from the centre of the Zakho city as shown in the Fig. 1. This large concentration of the lead was due to the fact that the area was overcrowded by industrial wastes, the smoke that emitted from the vehicles, as well as a big number of cars, also the values prove that leaded fuel is commonly used by automobiles in Zakho district and also around, Kurdistan region - Iraq. Furthermore, the least concentration of the lead was recorded with sample number S1 is $0.541 \mathrm{mg} / \mathrm{L}$, being taken from the entrance of Ibrahim Khalil area as shown in the Fig.1. The reason was that this area is far distant from the industrial wastes and there are large numbers of agriculture crops near the area. In addition, as seen in the Fig. 2, the concentration of $\mathrm{Pb}$ ion in soil from the sample $\mathrm{S} 1$ to $\mathrm{S} 18$ is similar, but the concentrations appeared to increase from S18 to S26 due to industrial emissions from the close productions and vehicular releases.

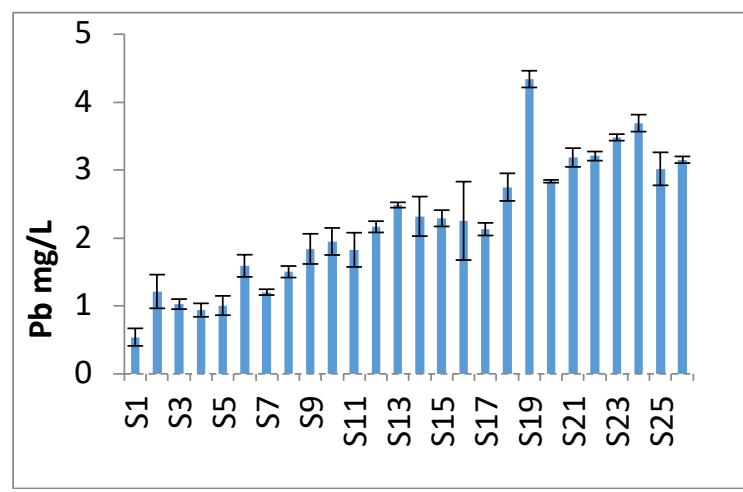

Figure 2. Pb concentration.

\subsection{Copper $\left(\mathrm{Cu}^{2+}\right)$}

The concentration of all samples was analysed for their $\mathrm{Cu}$ contents by AAS. $\mathrm{Cu}$ concentration shows small variety in the sampling points for soil samples. In addition, there were no significant differences in the distributions of $\mathrm{Cu}$ among even the same soil samples as shown in the Table 1 . The highest concentration for $\mathrm{Cu}$ was found in $\mathrm{S} 23(0.797 \mathrm{mg} / \mathrm{L})$ and it was taken from the city centre of Zakho. The smallest concentration was found in the sample no.S26 $(0.188 \mathrm{mg} / \mathrm{L})$ as seen in the table 1 . However, $\mathrm{Cu}$ level was found to be lower than all other heavy metals in all samples. In the soil, $\mathrm{Cu}$ strongly complexes to the organic implying that only a small fraction of copper was to be found in solution as ionic copper. The solubility of $\mathrm{Cu}$ is drastically increased at $\mathrm{pH} 5.5$ [13], which is rather close to the ideal farm and $\mathrm{pH}$ of $6.0-$ 6.5 [14]. Finally, as shown in the Fig. 3, the result reveal that the $\mathrm{Cu}$ concentration in all soil samples have almost the same concentration, which it is below the permissible limit and non-influence the quality of soil.

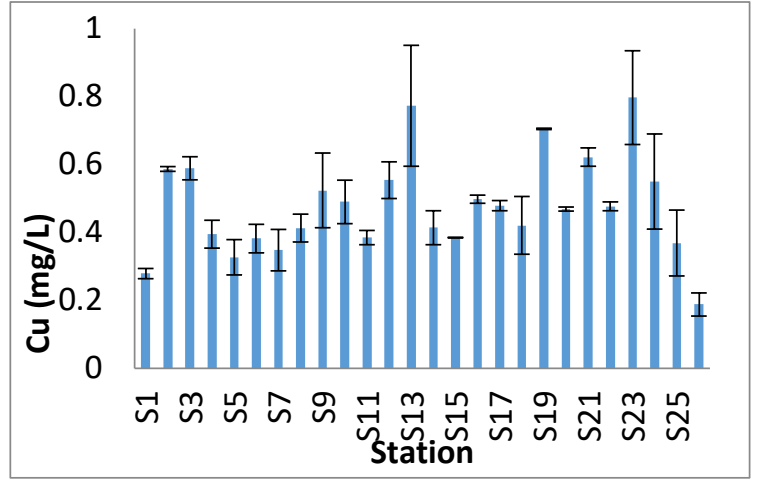

Figure 3. $\mathrm{Cu}$ concentration

\subsection{Zinc $\left(\mathrm{Zn}^{2+}\right)$}

Zinc $(\mathrm{Zn})$ is one of the essential heavy metal in soil. If the concentration of $\mathrm{Zn}$ is higher than the permissible limit (600 $\mathrm{mg} / \mathrm{L}$ ), it will reduce soil quality and may procure to human consumption through the tropic food web and damage human being. Maybe $\mathrm{Zn}$ concentration is rising unnaturally due to anthropogenic additions [15]. As shown in the table 1, the concentration of $\mathrm{Zn}$ shows higher than all other heavy metal but it is still below the permissible limit. However, the higher concentration of $\mathrm{Zn}$ recorded via AAS is sampled no. S5 by 5.540 $\mathrm{mg} / \mathrm{L}$ (Table 1. In Fig. 4). This is due to the fact that the soil is contaminated by the influents of traffic jam from the vehicular emissions and nearby industrial area. In addition, the lower concentration is in sample No.S15 by $1.26 \mathrm{mg} / \mathrm{L}$. All in all, the concentration of $\mathrm{Zn}$ started to increase from $\mathrm{S} 1$ to $\mathrm{S} 6$ then reduced gradually from S6 to S26, see (Fig. 2).

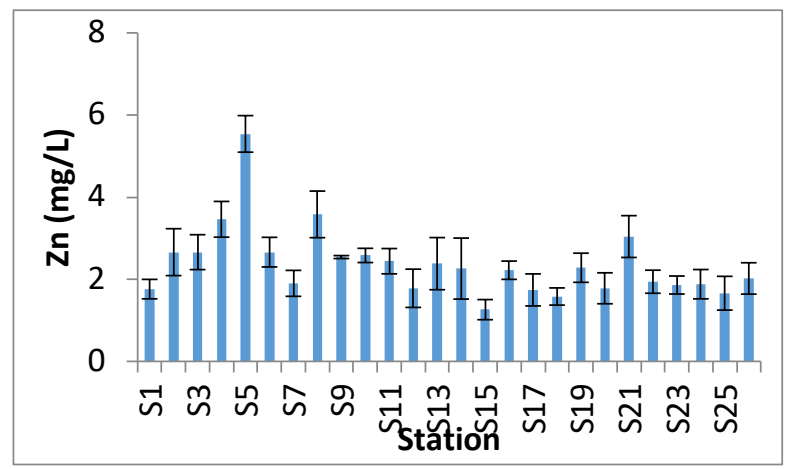

Figure 4. $\mathrm{Zn}$ concentration

\subsection{Nickel $\left(\mathrm{Ni}^{2+}\right)$}

Nickel is one of the elements which occur in the environment at very low levels, but can be dangerous also in low doses [16]. The recent study found that $1.05 \mathrm{mg} / \mathrm{L}$ was the lowest concentration of $\mathrm{Ni}$ in the study area at $\mathrm{S}$, then gradually increased in the direction to the down town, then to the highest one $-1.64 \mathrm{mg} / \mathrm{L}$ in S25 (Table 1, Fig 5). These data show that the concentration of $\mathrm{Ni}$ is even less than the allowed range $(10-1000 \mathrm{mg} / \mathrm{L}$ in most contaminated location because the only source of $\mathrm{Ni}$ in the area is fossil fuel combustion which seems higher in the city centre of Zakho. Based on [16, 17], the major sources of Ni in soil are 1) metal plating industries, 2) combustion of fossil fuels, 3) manufacturing of batteries, and 4) nickel mining and electroplating. 


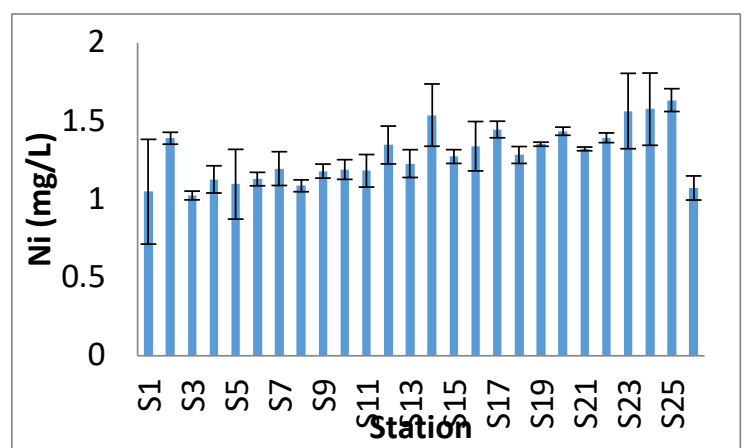

Figure 5. Ni concentration

\subsection{Chromium $\left(\mathrm{Cr}^{3+}\right)$}

Chromium is one of the less common elements and does not occur naturally in elemental form, but only in compounds. It is mined as a primary ore product in the form of the mineral chromite, $\mathrm{FeCr} 2 \mathrm{O} 4$. Major sources of $\mathrm{Cr}$ contamination include releases from electroplating processes and the disposal of $\mathrm{Cr}$ containing wastes. Despite that the soil is not contaminated in the area, the present study data, with very low concentration abundance between sites, recorded 1.32 $\mathrm{mg} / \mathrm{L}$ as lowest concentration of $\mathrm{Cr}$ in the area in S26 and the highest one was $2.1 \mathrm{mg} / \mathrm{L}$ in S14 (Table 1 and Fig. 6). These data illustrate that the area is not contaminated by $\mathrm{Cr}$, while the allowed value of $\mathrm{Cr}$ concentration in soil is $20 \mathrm{mg} / \mathrm{L}$ [16]. It refers mostly to the absence of mining process and electronically manufactures in the studied zone.

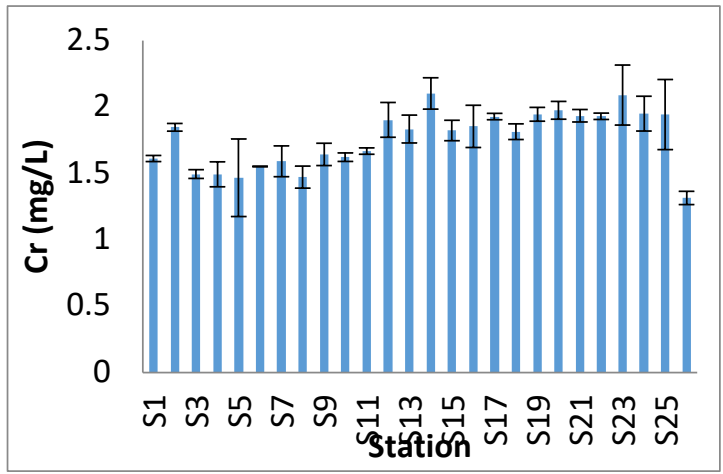

Figure 6. Cr concentration.

\section{CONCLUSION}

This study concludes that the twenty six soil samples collected from different area of Zakho district in Kurdistan region - Iraq, have been determined by using AAS technique for five heavy metals $\left(\mathrm{Pb}^{2+}, \mathrm{Cu}^{2+}, \mathrm{Zn}^{2+}, \mathrm{Cr}^{3+}\right.$ and $\left.\mathrm{Ni}^{2+}\right)$ for evaluation the human health risk due to high concentrations of five heavy metals in soils.

According to the data of AAS, the concentration of all heavy metals in the industrial and city centre soil samples are higher than their other point, to be more exact, the contamination levels of $\mathrm{Pb}$ and $\mathrm{Zn}$ are higher than $\mathrm{Cu}, \mathrm{Cr}$ and $\mathrm{Ni}$, due to industrial and human activities. However, the sources of the heavy metals pollution for the main road and city centre of Zakho district are commercial, industrial and traffic sources. Additionally, high quantity of fertilizer, pesticide application is two leading sources of contamination in the agricultural area.
Finally, the results indicates the main sources of the high level of the some heavy metals in soil samples in Zakho destruct originate from traffic, industrial and agriculture activities. Despite that, the level of pollution by heavy metals in the area is still under the international limits of the studied metals.

\section{REFERENCE}

Yu, S., Y.-g. Zhu, and X.-d. Li, 2012. Trace metal contamination in urban soils of China. Science of the total environment, 421: p. 17-30.

2. Khorshid, M.S.H. and S. Thiele-Bruhn, 2016. Contamination status and assessment of urban and non-urban soils in the region of Sulaimani City, Kurdistan, Iraq. Environmental Earth Sciences, 75(16): p. 1171.

3. Strumylaite, L., et al., 2014. Association between cadmium and breast cancer risk according to estrogen receptor and human epidermal growth factor receptor 2: epidemiological evidence. Breast cancer research and treatment, 145(1): p. 225-232.

4. Al-Hamzawi, A.A. and M.G. Al-Gharabi, 2019. Heavy metals concentrations in selected soil samples of Al-Diwaniyah governorate, Southern Iraq. SN Applied Sciences, 1(8): p. 854 .

5. Wong, C.S., X. Li, and I. Thornton, 2006.Urban environmental geochemistry of trace metals. Environmental pollution, 142(1): p. 1-16.

6. Amato, F., et al., 2009. Spatial and chemical patterns of PM10 in road dust deposited in urban environment. Atmospheric Environment, 43(9): p. 1650-1659.

7. Ajmone-Marsan, F. and M. Biasioli, 2010. Trace elements in soils of urban areas. Water, Air, \& Soil Pollution, 213(1-4): p. 121-143.

8. Trujillo-González, J.M., et al., 2016. Heavy metal accumulation related to population density in road dust samples taken from urban sites under different land uses. Science of the total environment, 553: p. 636-642.

9. Rudolf, M., 2019. Conceptualising crisis, refugees and IDPs: insights from northern Iraq on vulnerabilities and needs caused by displacement.

10. Maurya, A., L. Kesharwani, and M.K. 2018. Mishra, Analysis of Heavy Metal in Soil through Atomic Absorption Spectroscopy for Forensic Consideration. Int. J. Res. Appl. Sci. Eng. Technol, 6: p. 231-242.

11. Aclan, G., et al., Determination of Lead in Soil and Plants and Risk Assessment of its Effects among Preschool Children in Daycare Center in Manila, Philippines.

12. Alaboudi, K.A., B. Ahmed, and G. Brodie, 2018. Phytoremediation of $\mathrm{Pb}$ and $\mathrm{Cd}$ contaminated soils by using sunflower (Helianthus annuus) plant. Annals of agricultural sciences, 63(1): p. 123-127.

13. Martınez, C. and H. Motto, 2000. Solubility of lead, zinc and copper added to mineral soils. Environmental pollution, 107(1): p. 153-158.

14. Eriksson, J., A. Andersson, and R. Andersson, 1997. The state of Swedish farmlands. Swedish Environmental Protection Agency. Stockholm, Sweden: Tech. Rep,: p. 4778.

15. Harmanescu, M., et al., 2011. Heavy metals health risk assessment for population via consumption of vegetables grown in old mining area; a case study: Banat County, Romania. Chemistry Central Journal, 5(1): p. 64.

16. Wuana, R.A. and F.E. Okieimen, 2011.Heavy metals in contaminated soils: a review of sources, chemistry, risks and best available strategies for remediation. Isrn Ecology, 2011.

17. Chauhan, S., R. Thakur, and G. Sharma, 2008. Nickel: its availability and reactions in soil. Journal of Industrial Pollution Control, 24(1): p. 1-8. 